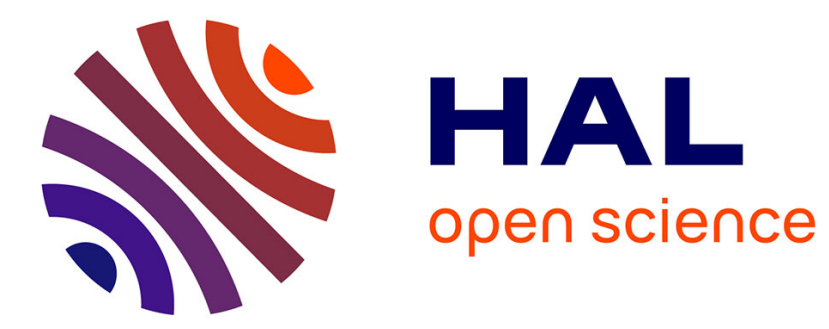

\title{
EXAFS STUDY OF A QUITE RELAXED ZINC-BLENDE LATTICE : THE GaAsySb1-y ALLOY
}

A. Marbeuf, F. Karouta, H. Dexpert, P. Lagarde, A. Joullié

\section{To cite this version:}

A. Marbeuf, F. Karouta, H. Dexpert, P. Lagarde, A. Joullié. EXAFS STUDY OF A QUITE RELAXED ZINC-BLENDE LATTICE: THE GaAsySb1-y ALLOY. Journal de Physique Colloques, 1986, 47 (C8), pp.C8-369-C8-373. 10.1051/jphyscol:1986872 . jpa-00226194

\section{HAL Id: jpa-00226194 https://hal.science/jpa-00226194}

Submitted on 1 Jan 1986

HAL is a multi-disciplinary open access archive for the deposit and dissemination of scientific research documents, whether they are published or not. The documents may come from teaching and research institutions in France or abroad, or from public or private research centers.
L'archive ouverte pluridisciplinaire HAL, est destinée au dépôt et à la diffusion de documents scientifiques de niveau recherche, publiés ou non, émanant des établissements d'enseignement et de recherche français ou étrangers, des laboratoires publics ou privés. 


\title{
EXAFS STUDY OF A QUITE RELAXED ZINC-BLENDE LATTICE : THE GaAs $\mathrm{Sb}_{1-\mathrm{y}}$
} ALLOY

\author{
A. MARBEUF, F. KAROUTA* ${ }^{*}$ H. DEXPERT ${ }^{*}$, P. LAGARDE* * and \\ A. JOULLIE*
}

Laboratoire de physique des solides, CNRS, 1, Place A. Briand. F-92195 Meudon Principal Cedex, France

* Equipe de Microoptoélectronique de Montpeliier, UA 392, USTL, F-34060 Montpellier Cedex, France

* LURE, Bâtiment 209C, Université Paris-Sud, F-91405 Orsay Cedex, France

\begin{abstract}
Résumé : Les spectres EXAFS après les seuils $\mathrm{K}$ de Ga et As, et LIII de Sb sur $\overline{\mathrm{GaAs}} \mathrm{y}_{\mathrm{S}} \mathrm{y}$ ont été enregistrés. L'analyse des spectres, dans le cas du seuil Ga, pour des compositions situées de part et d'autre de la lacune de miscibilité $(0 \leqslant y \leqslant .11, \propto 9 \leqslant y \leqslant 1)$, conduit aux distances entre $G a$ et ses plus proches voisins (NN). La distribution des distances cation-anion est bimodale (d (Ga-As)= $2.46 \pm .02 \AA, \mathrm{A}(\mathrm{Ga}-\mathrm{Sb})=2.63 \pm .01 \AA)$ et très proche de 1 a limite de PAULINGHUGGINS. Cette grande relaxation de la structure blende de zinc s'explique bien à 1a lumière d'un modèle de champ de forces de valence (Keating), en cherchant pour quelle configuration. les forces élastiques agissant sur chaque atome s'annullent: les deux sous-réseaux apparaissent distordus, tandis qu'une distribution multimodale des distances entre seconds voisins (NNN) est prédite,en accord avec l'élargissement du pic correspondant de la fonction de distribution radiale.
\end{abstract}

\begin{abstract}
EXAFS measurements above the K-edge of Ga, As and the LIII-edge of Sb in GaAsy $\mathrm{Sb}_{1-y}$ are performed. The analysis of data above the Ga K-edge, on both sides of the miscibility gap $(0 \leqslant y \leqslant .11, .9 \leqslant y \leqslant 1)$, leads to nearest-neighbor (NN) distances around $\mathrm{Ga}$ atom. The distribution of cation-anion distances is bimoda1 $(\mathrm{d}(\mathrm{Ga}-\mathrm{As})=2.46 \pm 02 \AA, \mathrm{d}(\mathrm{Ga}-\mathrm{Sb})=2.63 \pm .01 \AA)$ and very close to the PAJLING-HUGGINS 1imit. This great relaxation of the zinc-blende structure is explained by using a Valence-Force-Field model (Keating) and searching for the configuration at which the elastic forces acting upon every atom vanish : both sublattices are distorded and multimodal second-neighbor distribution of distance is predicted, in agreement with the broadening of the corresponding peak of the radial distribution. (NNN distances).
\end{abstract}

\section{Introduction.}

Among the III V and II VI pseudobinary systems, GaAs $\mathrm{Sb}_{1-\mathrm{y}}$ is interesting because of its miscibility gap below peritectic transformation $\left(t=747^{\circ} \mathrm{C}\right)$ which allows one to predict clustering tendency [1]. Further crystallographic information is needed to understand this behaviour which may influence the carrier mobility of the alloy or Iimit device feasability[2-3]. On the other hand, alloy description by the virtual crystal approximation (VCA) [4] is probably unadequate, as shown in other materials [5-7]. However, a local structure study such as EXAFS analysis can provide precise information on the GaAs $\mathrm{Sb}_{1-\mathrm{y}}$ zinc blende lattice. 


\section{Sample preparation and analysis technics.}

Bulk materials were Bridgman grown by cooling Ga-rich melt $\left(\mathrm{x}_{\mathrm{Ga}}^{P}=.50, t=800-\right.$ $1150^{\circ} \mathrm{C}$ ). Homogeneous ingots were selected by microprobe analysis of $\mathrm{X}$-Ray diffraction measurements of the lattice parameter $a^{\circ}(y)[8]$. Samples were then powdered (crystallile size smaller than $15 \mu \mathrm{m}$ ).

$\mathrm{GaSb}$ and GaAs were taken as structural standards for extracting the backscattering-amplitudes and phases used in the EXAFS analysis. Absorption spectra around $\mathrm{Ga}$ (As) $\mathrm{K}$-edge and $\mathrm{Sb} \mathrm{L}_{\text {III }}$-edge were performed at LURE (ORSAY, FRANCE) using either a double $\mathrm{Si}(311)$ crystal or a $\mathrm{Si}(400)$ channel cut monochromator. The DCI storage ring energy was $1.72 \mathrm{eV}$ and the electron current was typically $180 \mathrm{~mA}$.

The EXAFS modulation function $\chi(k)$ was extracted from the background with a Victoreen fit of the pre-edge, followed by a fit of the atomiclike smooth background $(*)$. The $k^{3} \chi(k)$ data are Fourier-transformed to real space and the contribution of the first shel1 (NN atoms) or the second shell (NNN atoms) is backtransformed.

\section{Results.}

The radial distribution functions $F(R)$ around the Ga or the As K-edge are suitable for analysis, but not the ones around the $\mathrm{Sb} \mathrm{L}$ III-edge because of the poor resolution due to the small energy range accessible between $\mathrm{L}_{I I I}$ and $\mathrm{L}_{I^{-}}{ }^{-}$ edge : $\Delta E=250 \mathrm{eV}$. Fig. 1 shows $\mathrm{F}(\mathrm{R})$ spectra around the Ga $\mathrm{K}$-edge for $\mathrm{y}=.11$ and $y=.90$. The first peak corresponding to $\mathrm{Ga}-\mathrm{V}$ distances ( $\mathrm{V}=\mathrm{As}, \mathrm{Sb}$ ) was filtered in the range $1.80-2.75 \AA$ and Fourier-backtransformed before fitting. From the adjustment of the resulting $k^{3} x(k)$ up to a maximum of $16 \AA^{-1}$ and using GaAs and $\mathrm{GaSb}$ as reference compounds, the NN distances have been derived. As shown by Fig. 2 and Fig. 3, the fit requires two anion

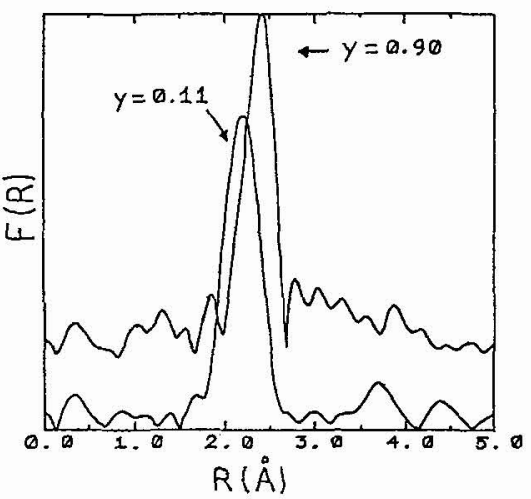
subshells around $\mathrm{Ga}$ atoms: thus, the distribution of $\mathrm{d}_{\mathrm{NN}}$ is bimodal ( $\mathrm{d}_{\mathrm{Ga}-\mathrm{As}} \neq$ $\mathrm{d}_{\mathrm{Ga}-\mathrm{Sb}}$ ) with a relaxation parameter of the lattice $\varepsilon=\left[\mathrm{d}_{\mathrm{Ga}-\mathrm{Sb}}-\mathrm{d}_{\mathrm{Ga}-\mathrm{As}}\right]$ / $\left[\left(a_{G a S b}^{0}-a_{G a A s}^{0}\right) \sqrt{3} / 4\right.$.] which does not vary with y $\left(\varepsilon_{\exp } \simeq 0.90\right)$.



Fig.1-Radial distribution function of $\mathrm{Ga}$ $\mathrm{K}$-edge spectra of $\mathrm{GaAs}_{\mathrm{y}} \mathrm{Sb}_{1-\mathrm{y}}$.

Fig.2-Experimental $k^{3} \chi(k)(\ldots)$ fitted with 1 anion subshel1 (-) for the composition $\mathrm{y}=0.90$.

* All computer calculations (Analysis \& Model)have been made at CIRCE (ORSAY,FRANCE). 


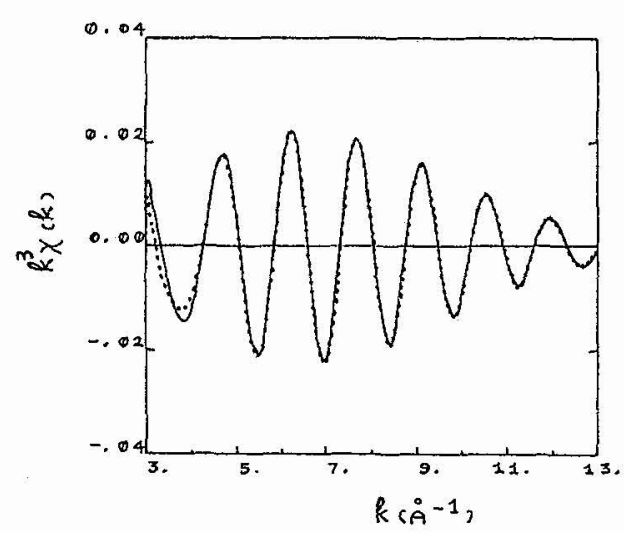

Fig.3-Experimental $k^{3} \chi(k)(\ldots)$ fitted with 2 anion subshells ( $\rightarrow$ for the composition $\mathrm{y}=0.90$.

Fitting results with fixed $\mathrm{As}$ and $\mathrm{Sb}$ atom numbers are listed in Table $\mathrm{I}$.

Table I - Parameters used in the fit $\left(\sigma^{2}\right.$ are Debye-Waller factors, $\Delta E_{0}$ is the edge shift, $\mathcal{R}$ is the reliability factor).

\begin{tabular}{|c|c|c|c|c|c|c|c|c|}
\hline $\mathrm{y}$ & ${ }^{\mathrm{N}} \mathrm{As}$ & $\mathrm{d}_{\mathrm{Ga}-\mathrm{As}}(\stackrel{\circ}{\mathrm{A}})$ & $\mathrm{N}_{\mathrm{Sb}}$ & $\mathrm{d}_{\mathrm{Ga}-\mathrm{Sb}}(\stackrel{\circ}{\mathrm{A}})$ & $\begin{array}{l}\sigma_{\mathrm{Ga}-\mathrm{As}}^{2} \\
\left(10^{-2} \mathrm{~A}^{2}\right)\end{array}$ & $\begin{array}{l}\sigma^{2} \mathrm{Ga}-\mathrm{Sb} \\
\left(10^{-2} \AA^{2}\right)\end{array}$ & $\Delta \mathrm{E}_{\mathrm{o}}(\mathrm{eV})$ & $\mathcal{R}(\%)$ \\
\hline .006 & 0.03 & $2.45^{\circ}$ & 3.97 & 2.637 & 0.00 & 0.00 & -0.92 & 0.87 \\
\hline .027 & 0.09 & 2.49 & 3.91 & 2.640 & 0.00 & 0.00 & 1.62 & 0.13 \\
\hline .050 & 0.20 & 2.47 & 3.82 & 2.640 & 0.04 & 0.00 & 1.93 & 0.68 \\
\hline .065 & 0.26 & 2.47 & 3.79 & 2.640 & 0.00 & 0.00 & 3.05 & 0.48 \\
\hline .095 & 0.33 & 2.47 & 3.65 & 2.638 & 0.03 & 0.00 & 0.31 & 0.19 \\
\hline .11 & 0.44 & 2.47 & 3.56 & 2.631 & 0.04 & 0.00 & 0.39 & 0.38 \\
\hline .90 & 3.1 & 2.45 & 0.9 & 2.620 & 0.00 & 0.00 & -0.41 & 0.29 \\
\hline .95 & 3.8 & 2.45 & 0.2 & 2.631 & 0.00 & 0.00 & -2.33 & 0.25 \\
\hline
\end{tabular}

Similar analysis of the As K-edge for As-rich composition alloys ( $y \geqslant 0.90$ ) 1eads to $\mathrm{NN}$ distances $\mathrm{d}_{\mathrm{As}-\mathrm{Ga}}=2.447 \AA$ in excellent agreement with the above results.

The 12 NNN atoms around Ga atoms are $G a$ and contribute to the peaks of $F(R)$ between 3.20 and $4.70 \AA$. The shape of these peaks shows the presence of two main groups of $\mathrm{d}_{\mathrm{Ga}-\mathrm{Ga}}$. Due to the different $\mathrm{Ga}-\mathrm{As}$ and $\mathrm{Ga}-\mathrm{Sb}$ bondlengthes, it can be predicted that the Ga-Ga distances with an As atom between Ga atoms ( $\mathrm{d}_{\mathrm{Ga}-(\mathrm{As})-\mathrm{Ga}}$ ) will be shorter than the Ga-Ga distances with a $\mathrm{Sb}$ atom $\left(\mathrm{d}_{\mathrm{Ga}}-(\mathrm{Sb})-\mathrm{Ga}\right)$. In the simulation, amplitude and backscattering phase are extracted from the second shell of GaAs for Ga$\mathrm{As}-\mathrm{Ga}$ and from the second shell of GaSb for Ga-Sb-Ga. A bimodal behaviour of the $\mathrm{d}_{\mathrm{Ga}-\mathrm{Ga}}$ distribution is still found as follows for $\mathrm{y}=0.90$ :

$$
\begin{array}{cccc}
\mathrm{N}_{\mathrm{Ga}}=11.08 & { }_{\mathrm{Ga}}^{\mathrm{d}}(\mathrm{As})-\mathrm{Ga} & =3.998 \AA & \AA \\
\mathrm{N}_{\mathrm{Ga}}=1.40 \quad \mathrm{~d}_{\mathrm{Ga}-(\mathrm{Sb})-\mathrm{Ga}}=4.319 \AA & \sigma_{\mathrm{Ga}-(\mathrm{As})-\mathrm{Ga}}^{2}=0.00\left(10^{-2} \AA^{2}\right) \\
\Delta_{\mathrm{O}}=0.18 \mathrm{eV} & \mathcal{R}=0.22 \% & \sigma_{\mathrm{Ga}-(\mathrm{Sb})-\mathrm{Ga}}^{2}=0.03\left(10^{-2} \AA^{2}\right)
\end{array}
$$


These cation-cation distances are rather close to that in constituent binaries GaAs and GaSb. All these results indicate a quite relaxation of the blende structure.

\section{Structural model of the GaAs $\mathrm{Sb}-1-\mathrm{y}$ lattice.}

Because of the existence of the NN and NNN distances bimodal distribution, the lattice distorsion occurs in both fcc sublattices. In order to understand how zinc blende structure accomodates such distorsions, the Valence-Force-Field model (VFF) in the Keating's scheme [9] is used. In this approach, the deformation energy $U$ of each unit cell is expressed in terms of the variations of the scalar quantities $\bar{r}_{i} \cdot \bar{r}_{j}{ }^{\prime}$ :

$$
U=\sum_{i=1}^{4}\left\{\frac{3}{8 r_{0}^{2}} \quad \alpha_{i}\left[\Delta\left(\bar{r}_{i} \bar{r}_{i}\right)\right]^{2}+\sum_{s=1}^{2} \sum_{\substack{i, j \\ i>j}} \beta_{i j}\left[\Delta\left(\bar{r}_{i}^{s} \bar{r}_{j}^{\prime}\right)\right]^{2}\right\}
$$

Here $s$ and $s^{\prime}$ refer to the two atoms of the unit cell while $i, j$ refer to the 4 bonds connecting these two atoms with thrse at the vertices of each tetrahedron. U contains only two elastic constants $: \alpha_{i}\left(\alpha_{\text {GaAs }}\right.$ or $\alpha_{\text {GaSb }}\left[10_{-}\right)$which describes the central-part of the potential (bond-stretching) and $\beta_{i j}$ ( $\beta_{\mathrm{GaAs}}[10], \beta_{\mathrm{GaSb}}[10]$ and $\bar{\beta}=$ $\sqrt{\beta_{\mathrm{GaAs}} \cdot \overline{\mathrm{GaSb}}_{\mathrm{GaS}}}$ ) corresponding to the non-central forces (bond-bending); $r_{0}$ is the bond distance in the undistorded crystal ( $\left.r_{0}=a^{0} \sqrt{3} / 4\right)$. The computer simulation of the alloy lattice with an anion random distribution is carried out by searching for the configuration at which the elastic forces acting upon each atom vanish. In order to minimize the influence of the surface atoms, the cluster contains 1000 atoms. Atomic radial distributions $P(d)$ around $\mathrm{Ga}$, $\mathrm{As}$ or $\mathrm{Sb}$ are then obtained. In the case of $P(d)$ around $\mathrm{Ga}$, the bimodal distribution of $\mathrm{d}_{\mathrm{NN}}$ and $\mathrm{d}_{\mathrm{NNN}}$ is obtained as a result of a great relaxation in both sublattices (Fig. 4). Good agreement between experimental and

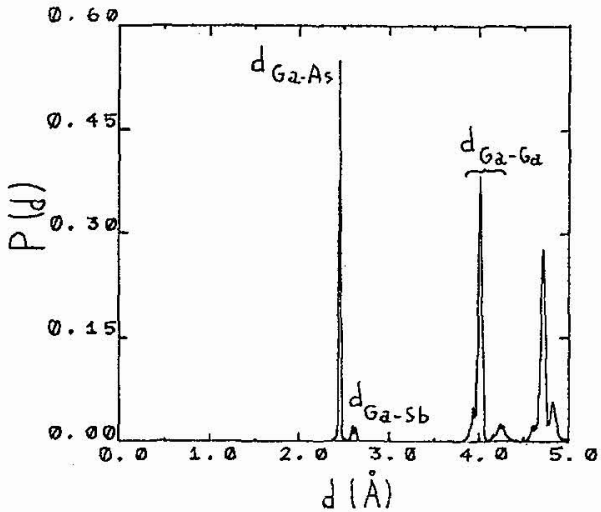

Fig.4- Calculated atomic radial distribution around $\mathrm{Ga}$ for GaAs. $90^{\mathrm{Sb}} \cdot 10$

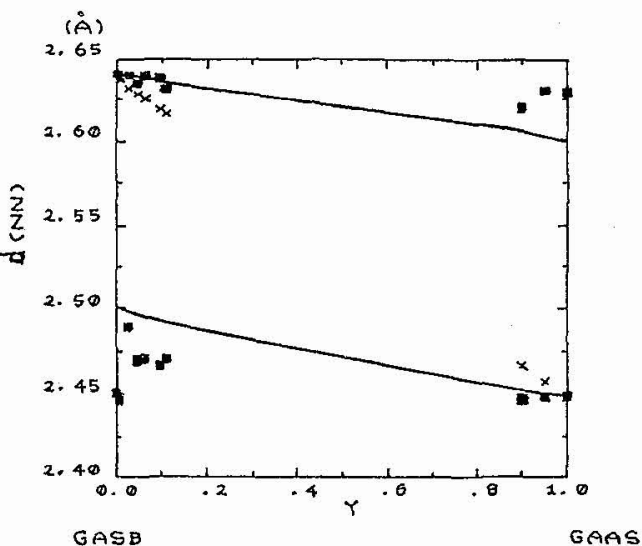

Fig.5-Calculated cation-anion distances $(-)$ in GaAs $\mathrm{Sb}_{1-\mathrm{y}}$ ( measured values, $\mathbf{X}$ Vegard's law).

calculated $d_{N N}$ is shown on Fig.5, but with a calculated relaxation parameter ( $\varepsilon_{\text {calc }}=$ 0.85) smaller than the experimental one $\left(\varepsilon_{\text {exp }}=0.90\right)$ and a slight variation versus $y$ of $\mathrm{d}_{\mathrm{Ga}-\mathrm{As}}$ and $\mathrm{d}_{\mathrm{Ga}-\mathrm{Sb}}$. The bimodal NNN distribution corresponds to the broadening of 
the corresponding peaks in $F(R)$. The root mean square deviation of the tetrahedron angle is less than $1.40^{\circ}$ around the $109.41^{\circ}$ mean value.

If a non-random distribution of anions is taken into account, calculations yield similar results. Thus, clear evidence of clustering tendency could be made by using other technics, such as X-Ray diffuse scattering.

\section{References}

[1] MARBEUf A. and GULLLAUME J.C., Rev. Phys. Appl. 19 (1984) 311.

[2] MARSH J.H., App1. Phys. Lett. 41 (1982) 732 .

[3] QUILLEC M., BENCHIMOL J.L., SLEMKES S. and LAUNOIS H.,Appl. Phys. Lett.42 (1983) 886 .

[4] VAN VECHTEN J.A. and BERGSTRESSER T.K., Phys. Rev. B1 (1970) 3351.

[5] MIKKELSEN J.C. and BOYCE J.B., Phys. Rev. B28 (1983) 7130 .

[6] BALZAROTTI A., KISIEL A., MOTTA N, ZTMNAL-STARNAWSKA M., CZYZYK M.T. and PODGORNY M., Phys. Rev. B30 (1984) 2295.

[7] MOTTA N., BALZAROTTI A., LETARDI P., KISIEL A, CZYZYK M.T., ZTMNAL-STARNAWSKA M. and PODGORNY M., J. Cryst. Growth, 72 (1985) 205.

[8] MANI H., Thèse de 3ème cycle, Université de Montpellier (1984), FRANCE

[9I KeAting P.N., Phys. Rev., 145 (1966) 637.

[10I MARTIN R.M., Phys. Rev., B1 (1970) 4005. 